At-Taradhi: Jurnal Studi Ekonomi

Volume XII Nomor I, Juni 2021

P-ISSN: 1979-3804, E-ISSN: 2548-9941

\title{
Analisis Sustainability Pengrajin Purun Kecamatan Haur Gading Amuntai
}

\section{Rahma Yuliani}

Fakultas Ekonomi dan Bisnis, Universitas Lambung Mangkurat, Indonesia. E-mail: rahma.yuliani@ulm.ac.id

\section{Widyakanti}

Fakultas Ilmu Sosial dan Ilmu Politik, Universitas Lambung Mangkurat, Indonesia. E-mail: kantiwidya@yahoo.com

\section{Adisti Rahmatiasari}

Fakultas Ekonomi dan Bisnis, Universitas Lambung Mangkurat, Indonesia. E-mail: adistrahmatia@gmail.com

\begin{tabular}{|c|c|}
\hline ARTICLE INFO & ABSTRACT \\
\hline $\begin{array}{l}\text { Cara Sitasi: } \\
\text { Yuliani, Rahma, } \\
\text { Widyakanti, dan } \\
\text { Adisti Rahmatiasari. } \\
\text { "Analisis } \\
\text { Sustainability } \\
\text { Pengrajin Purun } \\
\text { Kecamatan Haur } \\
\text { Gading Amuntai." } \\
\text { At-Taradhi: Jurnal } \\
\text { Studi Ekonomi 12, no. } \\
1 \text { (2021): 21-35. }\end{array}$ & 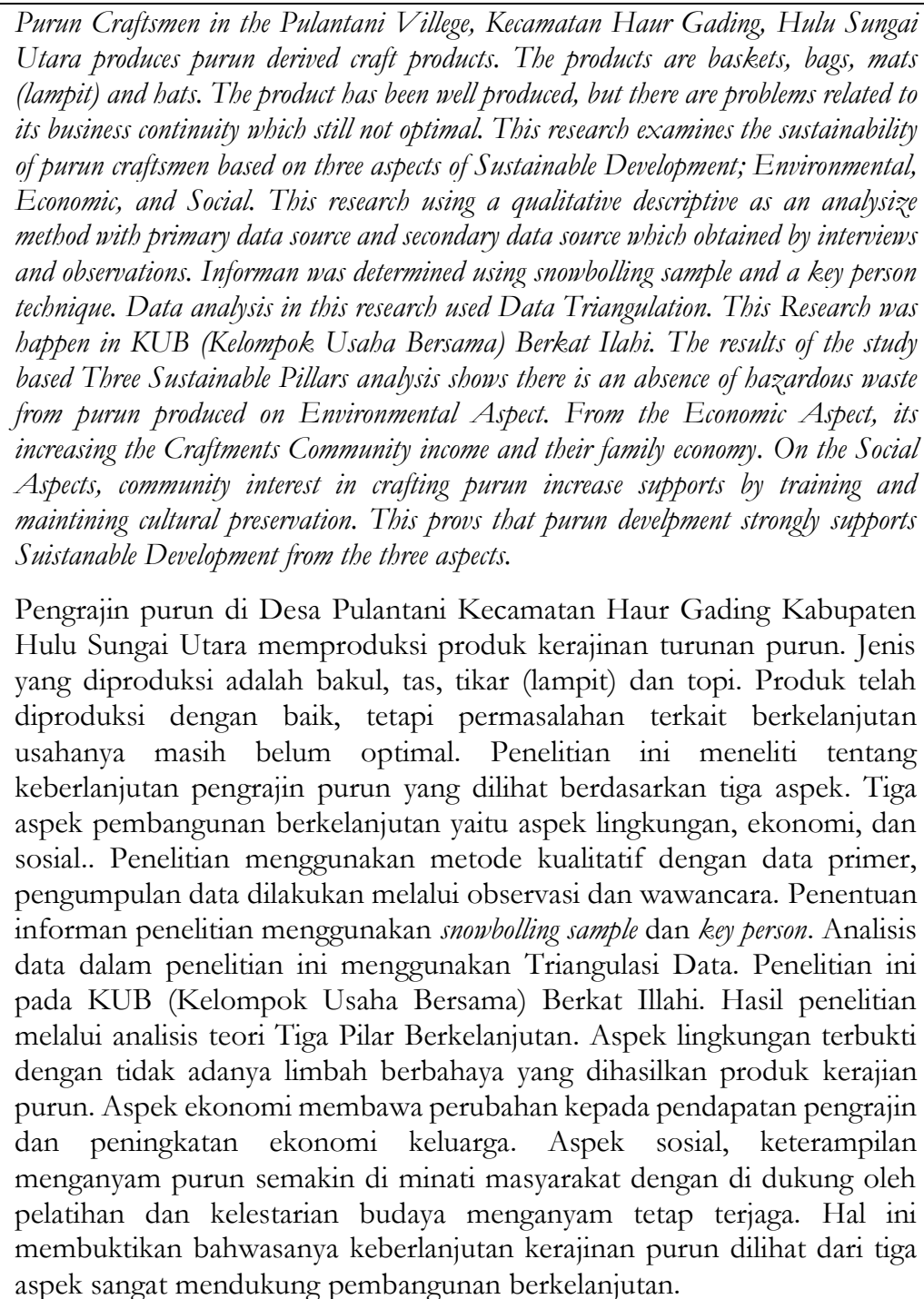 \\
\hline
\end{tabular}




\section{Pendahuluan}

Beberapa negara memperoleh manfaat dari kerajinan, karena kerajinan meruapakan bagian dari wisata budaya, sumber pekerjaan dan pendapatan bagi para pengrajin ${ }^{1}$. Kerajianan merupakan bagian dari pengalaman wisatawan yang mewakili tradisi lokal dan populasi pribumi, simbol dari tempat yang dikunjungi wisatawan dan pengalaman mereka ${ }^{2}$. Kerajianan yang ada di Inonesia sangat banyak dan bervariasi. Yavari berpendapat bahwa beberapa karakteristik kerajinan tangan adalah proses produksi yang di lakukan menggunakan tangan, bahan baku mentah berasal sumber daya lokal, memiliki makna budaya, masih membutuhkan investasi yang tinggi, membutuhkan nilai tambah yang tinggi jika di bandingkan industri lain ${ }^{3}$. Soeprapto menyatakan kerajinan merupakan keterampilan yang menggunakan tangan bukan pada mesin dan dibuat melalui proses ide - ide yang murni dan keindahan sehingga terciptanya suatu produk berkualitas dan bermutu seni ${ }^{4}$. Kerajinan purun yang di hasilkan dari menganyam purun merupakan salah satu kearifan lokal. Abbas E.W mengatakan kearifan lokal dapat berkembang ketika masyarakat lokal mampu beradaptasi kepada lingkungannya ${ }^{5}$. Mempertahankan tradisi merawat dan menganyam purun, selain meningkatkan perekonomian warga juga dapat menjaga kelestarian ekosistem gambut.

Ibrahim dalam penelitiannya menganalisis keberlanjutan pengrajin sutra di Sulawesi Selatan. Hasil penelitian menyatakan bahwa tingkat keberlanjutan kerajinan sutra kurang optimal $^{6}$. Analisis keberlanjutan menggunakan lima dimensi keberlanjutan. Kelima dimensi keberlanjutan terdiri dari dimensi ekonomi, sosial, lingkungan, kelembagaan dam perilaku kewirausahaan. Sánchez-Medina menyatakan bahwa aspek keberlanjutan ada tiga yaitu aspek ekonomi, sosial dan lingkungan? ${ }^{7}$. Penelitian tersebut menganalisis keberlanjutan usaha kerajinan kecil di Meksiko. Hasil penelitiaannya inovasi produk mempunyai peran besar dalam menentukan keberlanjutan pada tiga aspek tersebut. Aspek ekonomi di tentukan oleh tipe organisasi, inovasi produk dan inovasi organisasi. Aspek sosial ditentukan hanya oleh inovasi produk. Aspek lingkungan di tentukan oleh tipe organisasi, inovasi produk dan proses pada sebuah inovasi. 1 Foroogh Shojanoori et al., "An Analysis of the Environmental Factors Influencing the Handicraft
Development," Social Behavior and Personality 43, no. 10 (2015): https://www.researchgate.net/publication/308699947.

2 Mustafa., "Potential of Sustaining Handicrafts as a Tourism Product in Jordan" International Journal of Business and Social Science Vol. 2 No. 2; February

3 Yavari., “A Cursory Look At Management in Handicrafts Production Workshops” Azar Publications; Tehran.(2011)

${ }^{4}$ Erix Nando, "Peran Tenaga Kerja Wanita Pada Usaha Tikar Purun Di Desa Pedamaran VI Kecamatan Pedamaran Kabupaten Ogan Komering Ilir,” 2019.

${ }^{5}$ Nadia, "Kerajinan Anyaman Tikar Purun Sebagai Sumber Mata Pencaharian Warga Di Handil Marhanang

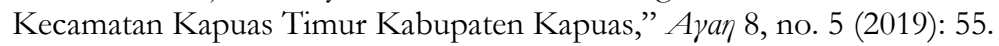

${ }^{6}$ Helda Ibrahim et al., "Analisis Keberlanjutan Usaha Pengrajin Ekonomi Kreatif Kerajinan Sutera Di Provinsi Sulawesi Selatan Sustainability,” Journal Teknologi Industri Pertanian 23, no. 3 (2013): 210-19.

${ }^{7}$ Sánchez-Medina et al., (2011) Environmental innovation and sustainability in small handicraft businesses in Mexico. Sustainability, 3(7), 984-1002. https://doi.org/10.3390/su3070984 
Pengembangan purun menjadi suatu kerajinan ini merupakan salah satu potensi pada lahan basah yang perlu diperhatikan agar dapat bermanfaat bagi budaya, sosial, serta yang paling utama yaitu ekonomi bagi suatu daerah. Potensi yang ada dalam lahan basah dapat menjadi penggerak ekonomi lokal apabila dapat dimanfaatkan secara bijaksana (www.Indonesia.wetlands.org). Potensi ini apabila dikelola dengan baik dan optimal maka tidak hanya memberi keuntungan bagi masyarakat tetapi juga bagi pemerintah misalnya menjadi salah satu sumber Penerimaan Asli Daerah (PAD) melalui perdagangan kerajinan tersebut kepada turis maupun masyarakat luas dari daerah setempat maupun luar daerah Hulu Sungai Utara ${ }^{8}$.

Purun (Lepironnia Articulata) merupakan tanaman liar yang tumbuh di area rawa? Tanaman ini tersebar di ekosistem payau yaitu ekosistem perantara antara ekosistem padang (rawa gambut) dan ekosistem Hapau (hutan gambut tropis basah). Populasi purun sangat bergantung pada keberadaan rawa \& hutan gambut tropis, yang menjaga tingkat keasaman air gambut yang berada di area padang tetap tinggi. Purun juga menjadi tempat favorit untuk berbagai spesies serangga dalam berkembang biak terutama bangsa capungcapungan (odonata). Tanaman purun dijadikan bahan serat utama bagi anyaman untuk membuat bakul, tas, tikar (lampit) dan topi. Pengolahan kerajinan purun menciptakan produk kreatif seperti sedotan dan sandal hotel yang lebih adaptif terhadap pasar. Tujuannya, selain untuk meningkatkan nilai jual dan keberlanjutan ekonomi melalui pemberdayaan desa. Kerajinan pengolahan purun menjadi sedotan dan sandal hotel juga mendukung program pemerintah dalam mengurangi penggunaan bahan-bahan plastik dan sterofoam yang merusak lingkungan.

Rofiqah \& Amalia dalam penelitiannya terkait Pengembangan Daya Saing Produk Pada Sentra Kerajinan Purun di Kabupaten Hulu Sungai Utara, dalam mengelola usaha, para pengrajin atau pelaku usaha menggunakan modal sendiri dalam memenuhi kebutuhan produksi kerajinan ${ }^{10}$. Para pengrajin ini tidak memiliki akses ke perbankan atau lembaga keuangan lain sebagai sumber modal, mereka lebih memilih menggunakan modal sendiri dalam struktur modal usaha dengan pertimbangan tingkat risiko dan kesulitan dalam hal aset yang dijadikan jaminan untuk mendapatkan dana tersebut. Selain itu faktor pengetahuan mereka menjadi faktor penghambat lainnya untuk akses ke lembaga keuangan ${ }^{11}$.

Keberlanjutan ekosistem gambut akan terjadi apabila industri pengolahan purun berjalan dengan baik dan mendatangkan keuntungan perekonomian bagi masyarakat desa Pulantani, Kecamatan Haur Gading, Kabupaten Hulu Sungai Utara. Hal ini meningkatkan ketergantungan masyarakat terhadap tumbuhan purun tentu akan meningkat. Melalui hal tersebut, maka masyarakat akan menjaga kelestarian ekosistem gambut dan Hapau agar tumbuhan purun tetap tersedia dan terjaga keberaadaannya demi mendukung industri

\footnotetext{
${ }^{8}$ Rofiqah Wahdah and Henny Septiana Amalia, "Pengembangan Daya Saing Produk Pada Sentra Kerajinan Purun Di Kabupaten Hulu Sungai Utara Kalimantan Selatan,” Jurnal Spread 6, no. 2 (2016): 89-99.

9 Wanapri Pangaribuan and Robert Silaban, "Upaya Peningkatan Pendapatan Wanita Pengrajin Purun (Eleocharis Dulcis) Di Kecamatan Perbaungan," Jurnal Pengabdian Kepada Masyarakat 23, no. 2 (2017): 309, https://doi.org/10.24114/jpkm.v23i2.6882.

${ }^{10}$ Rofiqah Wahdah and Amalia, "Pengembangan Daya Saing Produk Pada Sentra Kerajinan Purun Di Kabupaten Hulu Sungai Utara Kalimantan Selatan.” Jurnal Spread 6, no. 2 (2016): 89-99.

${ }^{11}$ Siska Fitriyanti, “The Analysis Of Smesbased On Itik Alabio \& Purun Commodities Development In Hulu Sungai Utara Regency," Jurnal Kebijakan Pembangunan 13 (2018): 67-72.
} 
pengolahan kerajinan mereka. Penelitian Mulyana ${ }^{12}$ serta penelitian Nando ${ }^{13}$ menyatakan bahwa pendapatan pengrajin purun dari tahun ke tahun mengalami peningkatan. Hal ini menunjukkan bahwa kegiatan menganyam purun memiliki kontribusi dalam menciptakan lapangan pekerjaan dan sumber penghidupan masyarakat. Apabila diperhatikan secara berkelanjutan, dan didukung oleh sarana dan prasarana yang memadai hal ini akan mampu meningkatkan kesejahteraan masyarakat.

Penelitian ini menganalisis keberlanjutan kerajinan purun dalam tiga pilar keberlanjutan menurut Chang (2015). Pilar tersebut adalah lingkungan, ekonomi dan sosial. Pembangunan berkelanjutan pada pilar lingkungan yaitu terkait pada pelayanan ekosistem, teknik dan bahan kimia yang berwawasan lingkungan, kualitas udara, kualitas air, tekanan dan integritas sumber daya. Pada pilar ekonomi yaitu terkait pekerjaan, insentif, supply and demand, perhitungan sumber daya alam, biaya dan harga. Pada pilar sosial yaitu, keadilan lingkungan, kesehatan manusia, partisipasi, pendidikan, keamanan sumber daya dan masyarakat yang berkelanjutan. Penelitian ini berbeda dengan penelitian yang dilakukan oleh Ibrahim ${ }^{14}$ serta oleh Sánchez-Medina ${ }^{15}$ dalam menganalisis karakteristik keberlanjutan dalam aspek lingkungan, sosial dan ekonomi.

\section{Tinjauan Pustaka}

\section{Pembangunan Berkelanjutan (Suistanable Development)}

Brundtland Report dari PBB (1987) mengatakan bahwa, pembangunan berkelanjutan merupakan mekanisme pembangunan dengan prinsip pemenuhan kebutuhan saat ini dengan tetap memperhatikan kebutuhan dimasa yang akan datang ${ }^{16}$. Ada dua konsep penting dalam pembangunan berkelanjutan (1) kebutuhan masyarakat miskin menjadi prioritas utama, (2) adanya keterbatasan organisasi sosial dan teknologi terhadap kemampuan lingkungan dalam memenuhi kebutuhan saat ini maupun dimasa yang akan datang.

Soemarwoto dalam Sutisna (2006) berpendapat bahwa terdapat enam indikator keberhasilan pembangunan berkelanjutan, yaitu:

a. Pro lingkungan hidup, diukur melalui kualitas udara, air, serta pencemaran lingkungan yang terjadi dimana hal ini dapat menjadi tolok ukur keberpihakan pemerintah terhadap keberlangsungan lingkungan

\footnotetext{
${ }^{12}$ Eka Mulyana, Elly Rosana, and Dewi Paramita, “Analisis Pendapatan Pengrajin Anyaman Tikar Purun Di Desa Tanjung Atap Kecamatan Tanjung Batu Kabupaten Ogan Ilir,” Prosiding Seminar Nasional 2017 Fakultas Pertanian UMJ "Pertanian Dan Tanaman Herbal Berkelanjutan Di Indonesia," 2017, 147-54, jurnal.umj.ac.id/index.php/semnastan.

${ }^{13}$ Erix Nando, "Peran Tenaga Kerja Wanita Pada Usaha Tikar Purun Di Desa Pedamaran VI Kecamatan Pedamaran Kabupaten Ogan Komering Ilir,” 2019.”

${ }^{14}$ Helda Ibrahim et al., "Analisis Keberlanjutan Usaha Pengrajin Ekonomi Kreatif Kerajinan Sutera Di Provinsi Sulawesi Selatan Sustainability,” Journal Teknologi Industri Pertanian 23, no. 3 (2013): 210-19.
}

${ }^{15}$ Sánchez-Medina et al., (2011) Environmental innovation and sustainability in small handicraft businesses in Mexico. Sustainability, 3(7), 984-1002. https://doi.org/10.3390/su3070984

${ }^{16}$ Nurman., "Strategi Pembangunan Daerah” (2015) 
b. Pro rakyat miskin, memberikan perhatian khusus kepada rakyat miskin karena takterurus pendidikannya, kesehatannya, berpenghasilan rendah, tidak memiliki akses permodalan usaha sehingga memiliki daya saing yang rendah

c. Pro kesetaraan gender/pro perempuan, yang dapat diukur melalui Genderrelated Develomentra Index (GDI) serta Gender Empowerment Measure (GEM) pada suatu wilayah.

d. Pro penciptaan lapangan kerja, dapat dilihat melalui keadaan demografi terkait jumlah Angkatan kerja dan jumlah masyarakat yang memiliki pekerjaan.

e. Pro dengan bentuk Negara kesatuan RI, pembangunan dapat berhasil apabila dalam prosesnya tidak menganggu kedaulatan Negara Kesatuan Republik Indonesia serta tidak adanya korupsi, kolusi dan nepotisme.

f. Anti korupsi, kolusi dan nepotisme.

\section{Tiga Pilar Pembangunan Berkelanjutan}

United States Environmental Protection Agency (USEPA) dalam Chang, (2015) ${ }^{17}$ bertujuan untuk dapat melaksanakan pembangunan melalui setiap aspek dalam pilar pembangunan yaitu:

a. Pilar Lingkungan

1) Pelayanan ekosistem: menjaga kelestarian alam serta kualitas ekosistem dan lingkungan hidup.

2) Teknik dan bahan kimia yang berwawasan lingkungan: meminimalisir adanya dampak kimia terhadap lingkungan yang mungkin timbul dari kegiatan manusia melalui kegiatan daur ulang, meminimalisir penggunaan bahan kimia, dan sebagainya.

3) Kualitas udara: menjaga kualitas udara melalui strategi minimalisir dampak emisi gas dengan tujuan menjaga tingkat polusi udara.

4) Kualitas air: menjaga kualitas air minum serta ekosistem air sebagai habitat ikan, udang, dan sebagainya.

5) Tekanan: meminimalisir adanya dampak tekanan terhadap kondisi masyarakat terkait keadaan lingkungan yang buruk misalnya polusi, efek rumah kaca, dan lain sebagainya. Tanaman purun merupakan jenis rumput liar yang sering tumbuh disekitar danau maupun rawa. Tumbuhan liar tersebut dimanfaatkan masyarakat sekitar kecamatan haur gading untuk dijadikan berbagai kerajinan tangan. Hal tersebut membawa dampak yang positif terhadap lingkungan maupun ekonomi masyarakat sekitar. Masyarakat sadar akan nilai dan manfaat purun sehingga mereka menjaga tumbuhan ini agar tidak hilang, sekaligus menjaga agar tidak terbakar di lahan gambut ketika musim kemarau tiba.

6) Integritas sumber daya: meminimalisir adanya dampak negatif terhadap lingkungan melalui pengelolaan sampah, kegiatan daur ulang, serta rehabilitasi atas terjadinya kerusahan sumberdaya. Mengingat banyak nya sampah plastik yang sulit untuk terurai, BRG mempunyai program Desa

\footnotetext{
${ }^{17}$ Chang et.al., " Sustainable Solid Waste Management" (2015).
} 
Peduli Gambut yang kemudian membuat sebuah inovasi terhadap tumbuhan purun yang tumbuh secara liar di kawasan rawa untuk dijadikan berbagai macam kerajinan tangan, diantaranya adalah tas yang terbuat dari tanaman purun, produk yang terbuat dari purun ini merupakan produk yang ramah lingkungan, sehingga kerajinan ini diharapkan dapat mengurangi sampah plastik yag membuat tercemarnya lingkungan sekitar.

b. Pilar Ekonomi

1) Pekerjaan: menciptakan peluang kerja yang berkelanjutan

2) Insentif: menciptakan insentif atau nilai tambah melalui motivasi masyarakat terhadap praktik berkelanjutan terhadap kondisi alam.

3) Supply and demand: meningkatkan peredaran harga melalui peningkatan kesejahteraan sosial, ekonomi, maupun Kesehatan masyarakat.

4) Perhitungan sumber daya alam: menciptakan produk - produk bernilai ekonomi yang berwawasan lingkungan

5) Biaya: Dampak positif biaya proses, layanan, dan produk (misalnya, berusaha untuk mengembangkan proses bebas sampah untuk menghilangkan kebutuhan untuk biaya regulasi)

6) Harga: Mempromosikan struktur biaya yang menyumbang eksternalitas produksi (misalnya, botol tagihan-minuman hukum penyimpanan kontainer) di seluruh Amerika Serikat dan di seluruh dunia)

c. Pilar Sosial

1) Keadilan lingkungan: melindungi hak masyarakat sehat dengan menciptakan lingkungan yang bersih dan sehat (contohnya, mengurangi polusi udara)

2) Kesehatan manusia: menjaga serta mengusahakan peningkatan terhadap Kesehatan masyarakat (contohnya, perancangan model yang bertujuan untuk memperkirakan tingkat toksikologi dalam pengembangan)

3) Partisipasi: adanya transparansi dengan keterlibatan pihak - pihak terkait (contohnya, penyediaan akses publik terkait pembangunan berkelanjutan)

4) Pendidikan: melindungi hak masyarakat untuk dapat memperoleh Pendidikan secara berkelanjutan.

5) Keamanan sumber daya: menjaga kelestarian alam maupun sumberdaya utama (contohnya, tanah, air, energi dan pengetahuan terkait hal yang dapat memberi dampak negatif terhadap hal tersebut).

6) Masyarakat yang berkelanjutan: memperkenalkan pengembangan, perencanaan, serta pembangunan berkelanjutan kepada masyarakat.

\section{Metode Penelitian}

Penelitian ini menggunakan pendekatan kualitatif. Pengumpulan data dilakukan melalui Forum Group Discussion (FGD), wawancara, observasi, serta dokumentasi (Bungin., 2012). FGD di lakukan secara bertahap: tahap pertama FGD membahas terkait keberlanjutan kerajinan purun di lihat dari aspek ekonomi, sosial dan lingkungan. Tahap kedua FGD 
dengan tujuan konfirmasi terkait hasil penelitian. FGD di hadiri oleh 15 pengrajin purun dan pihak - pihak pengurus BUD (Badan Usaha Bersama ). Wawancara secara langsung beberapa pengrajin untuk mengetahui lebih dalam keberlanjutan pengrajin purun. Wawancara di lakukan dengan mendatangi rumah pengrajin sehingga peneliti bisa melihat secara langsung dampak sosial dan ekonomi pada masyarakat pengrajin purun. Teknik analisis menggunakan triangulasi data, melalui tahapan sebagai berikut:

1. Hasil wawancara dan dokumentasi dikumpulkan. Hal - hal yang tidak terkait dengan tujuan penelitian dari hasil wawancara menjadi data akurat sehingga memungkinkan untuk dilakukannya penyajian dan penarikan kesimpulan atas data yang diperoleh. Pada penelitian ini, wawancara dilakukan kepada pengrajin purun dan warga setempat.

2. Penyajian data, yaitu penyusunan dan penampilan data secara sistematis dalam bentuk narasi sehingga berwujud konfigurasi yang memungkinkan dilakukan interprestasi kaitan antar data temuan kajian lapangan. Hasil wawancara disusun untuk kemudian dapat diambil kesimpulan. Dalam hal ini, dilakukan reduksi data yaitu hasil wawancara yang tidak sesuai dengan tujuan penelitian dikecualikan.

3. Penarikan kesimpulan, yaitu proses pencarian benang merah atas data yang telah disajikan dan diinterprestasikan dari hasil wawancara, Focus Group Discussion (FGD) dan observasi lapangan. Kalau ditemukan hal- hal yang belum mampu menjelaskan kaitan antar data, dilakukan pengecekan ulang atas data hasil kajian lapangan. Sebelum menarik kesimpulan akhir, terlebih dahulu bertukar pikiran dengan beberapa informan kunci untuk mengembangkan kesepakatan inter-subyektif melalui wawancara tambahan sampai ditemukan makna yang tersembunyi dari data yang disajikan untuk kemudian ditarik kesimpulan yang menjadi hasil penelitian.

\section{Hasil Penelitian}

Hasil penelitian melalui wawancara dan Focus Group Discussion (FGD) terkait produk kerajinan purun yang didasarkan tiga pilar pembangunan berkelanjutan, yaitu:

\section{Pilar Lingkungan}

a. Pelayanan ekosistem

“....kami sangat terbantu dengan adanya program pemberdayaan ini, selain menambah kreatifitas masyarakat, pemanfaatan tanaman purun ini juga dapat menjaga lingkungan...."

Tumbuhan liar tersebut dimanfaatkan masyarakat sekitar kecamatan haur gading untuk dijadikan berbagai kerajinan tangan. Hal tersebut membawa dampak yang positif terhadap lingkungan maupun ekonomi masyarakat sekitar. Masyarakat sadar akan nilai dan manfaat purun sehingga mereka menjaga tumbuhan ini agar tidak hilang, sekaligus menjaga agar tidak terbakar di lahan gambut ketika musim kemarau tiba.

b. Teknik dan bahan kimia yang berwawasan lingkungan

“....dalam pewarnaan kerajinan purun kami menggunakan warna yang aman serta terbuat dari bahan yang alami, agar tidak membuat kerusakan pada produk purun itu sendiri dan tidak membuat kerusakan pada lingkungan...." 
Limbah dari tumbuhan purun yang tidak berbahaya dan tidak merusak lingkungan, pewarna yang digunakan untuk mewarnai kerajinan purun pun merupakan pewarna yang aman, seperti yang disebutkan oleh Ibu Fatimah selaku pengrajin purun.

Kerajinan anyaman purun selalu menggunakan bahan - bahan yang ramah lingkungan sehingga tidak menimbulkan limbah yang dapat merusak lingkungan, sehingga kerajinan purun pantas untuk di pertahankan.

c. Tekanan

“....tanaman purun ini takutnya menjadi langka jika tidak dijaga oleh masyarakat, oleh sebab itu kami badan restorasi gambut memanfaatkan tanaman purun ini agar tidak mengalami kepunahan, sebab banyak manfaat yang ada ditumbuhan tersebut. Selain itu tujuan dari penjagaan tanaman purun itu sendiri agar tidak terjadi kebakaran di lahan gambut ketika musim kemarau tiba...."

Pihak badan restorasi gambut menjaga tumbuhan liar ini agar tidak hilang maupun langka, selain itu menjaga agar tidak terbakar di lahan gambut ketika musim kemarau tiba. Seperti yang diungkapkan oleh Iwan Hermawan selaku fasilitator Desa dan juga sebagai perwakilan dari badan restorasi gambut.

Kerajinan purun yang dilakukan masyarakat Desa Pulan Tani sekaligus dapat manjaga dan melestarikan keberadaan lahan gambut. Hal ini akan mengurangi tekanan dari luar yang sangat ingin mengubah lahan gambut menjadi area tambang.

d. Integritas sumber daya

“....dengan adanya produk kerajinan purun dalam bentuk tas ini kami berharap dapat mengurangi limbah plastik yang susah penguraiannya, serta masyarakat dapat beralih ke produk yang lebih ramah lingkungan...."

Produk kerajinan purun ini merupakan produk yang ramah lingkungan, selain itu produk kerajinan purun ini juga diharapkan dapat mengurangi sampah plastik yang membuat tercemarnya lingkungan sekitar. Seperi yang diungkapkan oleh Ibu Mardiah, selaku pengrajin purun.

Munculnya kerajinan purun seperti bakul, sandal dan tikar yang digunakan masyarakat akan mengurangi sampah plastik di lingkungan masyarakat desa.

Salah satu tujuan dari Pembangunan Berkelanjutan dalam Pilar Lingkungan yaitu bahwa adanya kegiatan yang tidak membayakan lingkungan sehingga tercipta kelestarian alam serta kualitas ekosistem yang terjaga dengan baik. Tanaman purun merupakan salah satu sumber daya alam di Kalimantan Selatan yang memiliki potensi untuk dieksplorasi lebih dalam terkait pemanfaatannya. Hasil penelitian menunjukkan bahwa pengolahan purun oleh pengrajin di Desa Pulantani, Kecamatan Haur Gading, Kabupaten Hulu Sungai Utara merupakan kegiatan yang ramah lingkungan karena fungsi produk olahan yang mampu menggantikan penggunaan plastik disamping proses pengolahan yang tidak menggunakan bahan kimia. Penelitian ini di dukung oleh 
penelitian Yoesran ${ }^{18}$ yang menyatakan bahwa kerajinan purun masih menggunakan pewarna alami.

Sifat tanaman purun yang mudah terbakar dalam keadaaan kering, memicu terjadinya kebakaran hutan pada saat musim kemarau ${ }^{19}$. Untuk mengurangi kebakaran tanaman purun pada musim kemarau maka masyarakat menjaga agar tanaman purun tidak terbakar, karena tanaman purun akan di jadikan bahan dasar kerajinan purun. Sehingga meningkatkan kesadaran masyarakat untuk menjaga kelestarian kondisi Purun, hal ini kemudian secara tidak langsung mengurangi terjadinya kebakaran lahan tersebut.

\section{Pilar Ekonomi}

a. Pekerjaan

'...ya, dengan adanya inovasi produk kerajinan purun ini bisa membuka lapangan kerja baru disebabkan dengan adanya inovasi yang bervariasi membuat para pengrajin juga belajar untuk membuat inovasi kerajinan purun yang baru. Yang awalnya mereka hanya mengolah kerajinan purun sekitar 2 macam variasi sekarang mereka bisa membuat lebih banyak variasi kerajinan purun. Pekerjaan sebagai pengrajin purun ini juga menjadi salah satu pekerjaan utama seperti di Desa Pulantani di kecamatan Haur Gading yang masyarakatnya hampir 90\% juga bekerja sebagai pengrajin purun. Pengarajin disini bekerja sesuai kemampuan mereka 1 hari per orang bisa 5-15 kerajinan yang mereka kerjakan. Dengan adanya inovasi kerajinan purun ini sangat memberdayakan dayakan masyarakat banyak yang tertarik karena dapat membantu perekeonomian masyarakat setempat..."

Dengan adanya inovasi produk kerajinan purun ini sangat membantu pengarajinpengrajin purun di kecamatan Haur Gading tepatnya di desa pulan tani. Awalnya, pengrajin hanya bisa membuat bakul dan tikar sekarang mereka bisa lebih banyak berinovasi. Sebagaimana yang diungkapkan oleh Iwan Hermawan selaku fasilitator desa pulantani. Hal ini juga menambah keahlian pengrajin dalam mengolah dan memproduksi purun, sehingga terciptanya ekonomi kreatif mandiri bagi masyarakat. Salah satu aspek pembangunan berkelanjutan yaitu ekonomi.

b. Penghasilan

"...Hasil dari kerajinan purun ini sangat membatu para pengrajin dari hasil tersebut mereka bisa sampai membiayai anak-anak mereka untuk mengembangkan pendidikan kejenjang yang lebih tinggi dan untuk memenuhi kehidupan mereka..."

Berkat usaha kelompok usaha bersama berkat ilahi bersama para pengrajin hasil dari inovasi kerajinan purun ini sangat bisa dirasakan dampaknya Sebagaimana yang diungkapkan oleh Iwan Hermawan selaku fasilitator desa pulantani. Inovasi produk purun menciptakan kegiatan ekonomi yang mampu memberikan penghidupan bagi pengrajin. Pengrajin memiliki keahlian untuk dapat menciptakan produk yang menarik dan beragam sehingga mampu menciptakan

\footnotetext{
18 Yoesran, M., Gunawansyah, \& R, A. A. Usaha Peningkatan Produktivitas'Tenaga Kerja dan Nilai Tambah Kerajinan Purun. Jurnal Hutan Tropis, 2 (2014), 176-188.

19 Wanapri Pangaribuan and Robert Silaban, "Upaya Peningkatan Pendapatan Wanita Pengrajin Purun (Eleocharis Dulcis) Di Kecamatan Perbaungan,” Jurnal Pengabdian Kepada Masyarakat 23, no. 2 (2017): 309, https://doi.org/10.24114/jpkm.v23i2.6882
} 
kualitas produk yang baik mampu meningkatkan pendapatan masyarakat karena produk memiliki nilai jual yang tinggi.

\section{c. Supply and Demand}

Untuk peningkatan ekonomi disini Kelompok Usaha Bersama Berkat Ilahi saling bekerjasama dengan kelompok usaha bersama lainnya untuk memenuhi permintaan konsumen. Melalui inovasi produk purun, pengrajin mampu menghasilkan produk yang lebih beragam dan menarik yang mampu menarik minat pelanggan dari berbagai kalangan maupun dari aspek fungsi produk itu sendiri. Sehingga permintaan terhadap produk menjadi meningkat. Sebagaimana yang diungkapkan oleh Iwan Hermawan selaku fasilitator desa pulantani:

“...selama ini pihak kelompok usaha bersama masih bisa memanajemen orderan yang ada dan juga saling bekerja sama dengan kelompok usaha bersama lainnya. untuk masalah harga kelompok usaha bersama kecamatan haur gading bekerjasama dengan kelompok usaha bersama lainnya untuk menyesuaikan harga, jadi tidak sembarangan menaikkan harga karna harga sudah disepakati sebelumnya agar tidak jauh berbeda. Dan untuk setiap bulannya permintaan konsumen naik turun tidak bisa dipastikan..."

d. Perhitungan sumber daya alam

Perhitungan sumber daya alam sangat penting untuk diperhatikan karna ini berkaitan langsung dengan kelestarian alam. Kelompok usaha bersama berkat ilahi juga sedang mengembangkan pembuatan kebun purun agar mendapatkan purun yang berkualitas serta memiliki harga jual yang tinggi untuk lebih meningkatkan lagi ekonomi masyarakat. Harapannya, dengan tersedianya kebun purun maka pengrajin dapat memiliki akses yang lebih mudah dalam memeroleh bahan baku purun disamping kelestarian tanaman purun dapat dikontrol dengan baik. Sebagaimana yang diungkapkan oleh Iwan Hermawan selaku fasilitator desa pulantani:

“...Dengan adanya inovasi purun ini menjadikan masyarakat lebih peduli terhadap alam dan pekerjaan mereka dan sekarang kelompok usaha bersama Kerajinan Purun Berkat Ilahi sedang mengembangkan pembuatan kebun purun yang dirawat dan akan menghasilkan purun yang berkualitas tinggi serta memiliki harga jual yang tinggi..."

e. Biaya

Masalah biaya pengolahan kerajinan purun ini masih rendah dan mencukupi karna kerajinan ini sebagian besar menggunakan bahan yang di ambil langsung dari alam serta diolah dengan anyaman tangan sehingga biaya yang di perlukan untuk pengolahan kerajinan purun ini tidak besar. Sebagaimana yang diungkapkan oleh Iwan Hermawan selaku fasilitator desa pulantani:

“...Untuk biaya pembuatan kerajinan purun tidak ada kendela sama sekali karena masyarakat mengambil bahan baku purun tersebut langsung dari alam yang masih berlimpah. Biaya yang dikeluarkan pembuatan kerajinan purun beraneka ragam tergantung besar dan tingkat kesulitan nya kalau di rata-rata pembutan kerajinan purun ini berkisar Rp. $9000 \ldots$... 


\section{f. Harga}

Dampak dari inovasi kerajinan purun ini sangat dirasakan oleh pengrajin sebab dengan inovasi kerajinan purun yang menarik dapat menaikkan harga jual kerajinan tersebut dengan modal yang terbilang hampir sama setiap pembuatan kerajinan purun. Melalui inovasi produk purun, pengrajin mampu menciptakan produk yang menarik dan memiliki nilai jual tinggi sehingga produk mampu dihargai dengan layak di pasaran. Sebagaimana yang diungkapkan oleh Iwan Hermawan selaku fasilitator desa pulantani:

“...untuk harga penjualan setiap kerajinan purun sekarang mengalami kenaikan yang sudah cukup memuaskan para pengrajin. Harga-harga yang dijual dari kerajinan purun juga disesuaikan dengan harga pasaran agar kerajinan purun tersebut dapat di beli dari semua kalangan..."

Salah satu inti dari tujuan dari Pembangunan Berkelanjutan dalam Pilar Ekonomi yaitu terciptanya lapangan pekerjaan yang berkelanjutan disamping efisiensi penggunaan bahan baku. Menurut Torang \& Doriyanto (2012:93), di Provinsi Kalimantan Selatan kegiatan menganyam purun telah ditekuni sebagai menjadi kegiatan usaha secara turun temurun ${ }^{20}$. Hal yang sama berlangsung di Desa Pulantani, Kecamatan Haur Gading, Kabupaten Hulu Sungai Utara. Kegiatan ini secara tidak langsung menjadi penggerak roda perekonomian melalui terciptanya kegiatan ekonomi kreatif bagi masyarakat, yaitu suatu konsep ekonomi dimana kreativitas dan pengetahuan Sumber Daya Manusia menjadi faktor produksi utama (Tim Design Indonesia, 2008) ${ }^{21}$. Kegiatan pengolahan purun kebanyakan dilakukan di rumah pengrajin masing - masing. Perkembangan industri rumahan secara berkelanjutan dalam suatu wilayah mampu meningkatkan pendapatan sehingga meningkatkan kesejahteraan masyarakat disamping kegiatan usaha yang dilakukan di rumah tinggal pengrajin mampu menciptakan efisiensi biaya tempat produksi hingga pemasaran ${ }^{22}$.

Sejatinya, perkembangan suatu usaha harus dibarengi dengan adanya inovasi, dimana pelaku bisnis harus mampu menciptakan strategi untuk dapat tetap bersaing dan meningkatkan pendapatannya ${ }^{23}$. Pesatnya perkembangan zaman, mengharuskan pengrajin untuk mampu menciptakan produk yang tidak terbatas pada bakul dan tikar seperti dahulu agar dapat beradaptasi ${ }^{24}$. Hasil penelitian menunjukkan melalui inovasi masyarakat mampu menciptakan produk yang lebih beragam dengan kualitas yang

\footnotetext{
${ }^{20}$ Achmad Reza Fahriannoor, “Kota Banjarbaru The Business Development Pattern of 'Purun ' Handycraft by Product Diversification in Kampung Purun Village, Cempaka Sub-District, Banjarbaru City" 3, no. 4 (2019): 8-17.

${ }^{21}$ Helda Ibrahim et al., "Analisis Keberlanjutan Usaha Pengrajin Ekonomi Kreatif Kerajinan Sutera Di Provinsi Sulawesi Selatan Sustainability,” Journal Teknologi Industri Pertanian 23, no. 3 (2013): 210-19.

22 Dwi Laras Lukitaningrum, Wido Prananing Tyas, and Mohammad Muktiali, "Analisis Keberlanjutan Home Based Enterprise Pengolahan Singkong Di Kota Salatiga," Jurnal Pengembangan Kota 5, no. 2 (2017): 166, https://doi.org/10.14710/jpk.5.2.166-180.

${ }^{23}$ Dorin Maier et al., "The Relationship between Innovation and Sustainability: A Bibliometric Review of the Literature," Sustainability (Switzerland) 12, no. 10 (2020), https://doi.org/10.3390/SU12104083.

${ }^{24}$ Irma Liyanawati and Rizal, "Analisis Pengembangan Home Industri Kerajinan Purun Di Kelurahan Palam Kecamatan Cempaka, Kota Banjarbaru,” Jurnal Ilmu Ekonomi Dan Pembangunan 2, no. 4 (2019): 959-71.
} 
lebih baik. Sehingga, produk yang dihasilkan masyarakat memiliki nilai jual yang tinggi dan dihargai dengan layak di pasaran.

\section{Pilar Sosial}

a. Keadaan lingkungan

Merupakan sesuatu yang dilihat akan memberikan dampak yang baik atau buruk terhadap lingkungan tersebut. Dimana yang awalnya masyarakat memproduksi produk kerajinan purun ini hanya dirumah masing-masing dengan memperoleh penghasilan yang kecil. Setelah berdirinya kelompok usaha bersama kerajinan purun berkat ilahi ini memberikan dampak yang positif bagi Desa Pulantani. Sebagaimana yang diungkapkan oleh Iwan Hermawan selaku fasilitator desa pulantani:

"...selama adanya kelompok usaha bersama kerajinan purun berkat ilahi ini tentunya memberikan dampak baik bagi lingkungan desa pulantani. Pengrajin dapat memproduksi produk kerajinan purun ini di kantor desa. Kemudian juga dampak yang dirasakan yaitu meningkatnya semangat kerja pengrajin karena adanya banyak pesanan dari konsumen sehingga memicu pengrajin untuk cepat menyelesaikan produk kerajinan purun yang mereka buat. Membeludaknya jumlah pesanan juga akan meningkatkan perekonomi pengrajin di desa Pulantani..."

b. Partisipasi

Adanya partisipasi ditunjukkan melalui keterlibatan masyarakat dalam setiap proses pengembangan masyarakat. Seperti pada Desa Pulantani, yang mana mayoritas masyarakatnya memiliki kemampuan membuat kerajinan tangan dari purun. Maka dari itu, dilakukan upaya untuk mengembangkan kemampuan kerajinan tangan dari purun ini dengan memberdayakan masyarat melalui kelompok usaha bersama kerajinan berkat ilahi. Sebagaimana yang dikatakan oleh Baihaqi selaku ketua Kelompok Usaha Bersama kerajinan purun berkat ilahi:

“...untuk pengrajin dari kelompok ini semuanya itu dari masyarakat desa pulantani. Sebab hampir 90\% masyarakat yang berada di desa pulantani ini memiliki kemampuan dalam membuat produk kerajinan purun. Kerajinan purun ini memang dianggap sebagai tradisi turun-temurun dari zaman dahulu..."

c. Pendidikan

Dalam upaya mengembangkan kerajinan purun ini maka biasanya kelompok usaha bersama kerajinan purun berkat ilahi ini mengadakan pelatihan untuk para pengrajin. Pelatihan ini biasanya dilakukan pada kantor desa ataupun diluar daerah. Pelatihan yang diadakan berkaitan dengan inovasi produk kerajinan purun berkat ilahi. Sebagaimana dikatakan oleh Ibu Rahmah selaku sekretaris kelompok usaha bersama kerajinan berkat ilahi:

“...pada awalnya pengrajin pada kelompok usaha bersama kerajinan purun berkat ilahi ini kami berikan beberapa pelatihan yang berkaitan dengan kerajinan purun. Yang mungkin awalnya pengrajin hanya bisa membuat bakul dan tikar. Setelah mengikuti pelatihan maka pengrajin bisa membuat berbagai macam produk kerajinan purun. Contohnya seperti tas, pot bunga, topi, kotak pensil, sendal. Dengan adanya pelatihan ini dapat meningkatkan kemampuan pengrajin dalam 
berinovasi dan dapat lebih kreatif. Tentu banyaknya inovasi kerajinan purun ini dapat menarik hati para konsumen..."

d. Keamanan Sumberdaya

Kecamatan Haur Gading kaya akan tanaman purun. Purun ini merupakan tanaman yang tumbuh liar pada lahan gambut. Karena memiliki serat yang kuat sehingga pengrajin memanfaatkan tanaman purun ini sebagai bahan baku dalam membuat produk kerajinan purun. Bahan baku ini selalu tersedia dan sangat mudah ditemukan sehingga membantu para pengrajin dalam memproduksi kerajinan purun dengan jumlah yang banyak.. Sebagaimana yang diungkapkan oleh Baihaqi selaku ketua kelompok usaha bersama kerajinan purun berkat ilahi:

“...bahan baku kerajinan purun ini yaitu dari tanaman purun. Alhamdulillah sampai saat ini kami belum pernah kesulitan dalam mencari bahan baku. Dan juga jumlahnya yang berlimpah memudahkan para pengrajin untuk membuat produk kerajinan purun tanpa takut bahan baku habis. Namun, tidak semua purun yang kami peroleh itu bagus. Terkadang memang ada purun yang tidak bersih tetapi karna dari pihak PT. Karya dua anyam yang menginginkan purun yang baik. Jadi kami biasanya memilah lagi purun yang bersih dan bagus agar dapat memperoleh produk kerajinan purun yang berkualitas tinggi..."

e. Masyarakat berkelanjutan

Program pemberdayaan diharapkan dapat berlanjut dan memberikan efek yang baik dimasa yang akan datang.Sebagaimana yang dijelaskan oleh Iwan Hermawan selaku fasilitator:

“...kelompok usaha bersama kerajinan purun berkat ilahi ini sudah berjalan selama hampir 2 tahun dan akan terus berlanjut ke masa yang akan datang. Kami melakukan perjanjian kontrak dengan PT. Karya dua anyam sampai tahun 2021. Kontrak tersebut biasanya akan diperpanjang kalau kualitas produk dari kelompok usaha bersama kerajinan purun berkat ilahi sesuai dengan yang diinginkan oleh PT. Karya dua anyam. Tentunya juga dengan adanya kelompok ini memberikan efek terhadap perekonomian yang semakin meningkat dan sekaligus dapat mensehjetarakan masyarakat di desa pulantani.

Hasil penelitian menunjukkan bahwa kegiatan menganyam purun memberikan manfaat yang besar dalam beberapa aspek yaitu ekonomi, sosial dan lingkungan. Dalam aspek ekonomi, kegiatan menganyam menjadi sumber pendapatan masyarakat. Hal ini sejalan dengan penelitian ${ }^{25}$ yang dilakukan di Desa Melati, Kabupaten Serdang Bedagai, Provinsi Sumatera Utara. Dalam aspek lingkungan, menganyam purun tidak menimbulkan dampak negatif terhadap lingkungan karena tidak menggunakan bahan kimia dalam proses pengolahannya, bahan kimia hanya digunakan dalam proses pewarnaan. Hal ini sejalan dengan penelitian Yoesran ${ }^{26}$, kelemahan dari tidak digunakannya bahan kimia yaitu berpengaruh pada tingkat kelenturan dan kekuatan purun. Dalam aspek sosial, kegiatan

\footnotetext{
25 Wanapri Pangaribuan and Robert Silaban, "Upaya Peningkatan Pendapatan Wanita Pengrajin Purun (Eleocharis Dulcis) Di Kecamatan Perbaungan," Jurnal Pengabdian Kepada Masyarakat 23, no. 2 (2017): 309, https://doi.org/10.24114/jpkm.v23i2.6882

${ }^{26}$ Yoesran, M., Gunawansyah, \& R, A. A. Usaha Peningkatan Produktivitas'Tenaga Kerja dan Nilai Tambah Kerajinan Purun. Jurnal Hutan Tropis, 2 (2014), 176-188
} 
menganyam purun menambah keterampilan masyarakat, pelatihan yang diadakan meningkatkan kreativitas masyarakat dalam berinovasi dan melakukan pengembangan produk. Hal ini sejalan dengan penelitian Fahrianoor ${ }^{27}$.

\section{Penutup}

Kesimpulan penelitian bahwa kerajinan purun akan mendukung pembangunan berkelanjutan. Berdasarkan tiga aspek yaitu ekonomi, sosial dan lingkungan. Kerajinan purun pertama dapat menambah penghasilan masyarakat, kedua pelatihan menganyam purun dapat mempertahankan kearifan lokal, ketiga kelestarian lahan gambut akan terjaga dengan baik. Purun dikelola KUBE Berkah Illahi akan terus berkelanjutan apabila ada keterdukungan dari pemerintah daerah terkait alat - alat proses produksi dan pendanaan. Saran untuk penelitian selanjutnya meneliti terkait strategi pengembangan kerajinan purun agar dapat bertahan di tengah pandemi Covid 19.

\section{Daftar Pustaka}

Bungin, Burhan. (2012). Penelitian Kualitatif. Jakarta: Kencana Perdana Media Group.

Chang, Ni-Bin dan Ana Pires. 2015. Sustainable Solid Waste Management. Amerika: IEEE Press Editorial

Fahriannoor, A. R. (2019). The Business Development Pattern of "Purun" Handycraft by Product Diversification in Kampung Purun Village, Cempaka Sub-district, Banjarbaru City. 3(4), 8-17.

Ibrahim, H., Amanah, S., Gani. S, D., \& Purnaningsih, N. (2013). Analisis Keberlanjutan Usaha Pengrajin Ekonomi Kreatif Kerajinan Sutera Di Provinsi Sulawesi Selatan Sustainability. Journal Teknologi Industri Pertanian, 23(3), 210-219.

Kessa, Wahyudin. (2015). Perencanaan Pembangunan Desa. Jakarta: Kementerian Desa, Pembangunan Daerah Tertinggal, Dan Transmigrasi Republik Indonesia.

Komarudin, M. A. (2017). Kebijakan Pemberdayaan Masyarakat Desa Daerah Perbatasan Di Kabupaten Sintang Tahun 2015 (Studi Kasus Badan Pemberdayaan Masyarakat Dan Pemerintah Desa Kabupaten Sintang)

Kurniawan, Borni. (2015). Desa Mandir, Desa Membangun. Jakarta: Kementerian Desa, Pembangunan Daerah Tertinggal, Dan Transmigrasi Republik Indonesia.

Liyanawati, I., \& Rizal. (2019). Analisis Pengembangan Home Industri Kerajinan Purun di Kelurahan Palam Kecamatan Cempaka, Kota Banjarbaru. Jurnal Ilmu Ekonomi Dan Pembangunan, 2(4), 959-971.

Lukitaningrum, D. L., Tyas, W. P., \& Muktiali, M. (2017). Analisis Keberlanjutan Home Based Enterprise Pengolahan Singkong Di Kota Salatiga. Jurnal Pengembangan Kota, 5(2), 166. https://doi.org/10.14710/ipk.5.2.166-180

Maier, D., Maier, A., Aşchilean, I., Anastasiu, L., \& Gavriş, O. (2020). The relationship

27 Achmad Reza Fahriannoor, "KOTA BANJARBARU The Business Development Pattern of “ Purun ' Handycraft by Product Diversification in Kampung Purun Village , Cempaka Sub-District, Banjarbaru City" 3, no. 4 (2019): 8-17. 
between innovation and sustainability: A bibliometric review of the literature. Sustainability (Switzerland), 12(10). https://doi.org/10.3390/SU12104083

Mairna Mustafa 2011" Potential of Sustaining Handicrafts as a Tourism Product in Jordan" International Journal of Business and Social Science Vol. 2 No. 2; February

Mulyana, E., Rosana, E., \& Paramita, D. (2017). Analisis Pendapatan Pengrajin Anyaman Tikar Purun Di Desa Tanjung Atap Kecamatan Tanjung Batu Kabupaten Ogan Ilir. 147-154.

Nando, E. (2019). Peran Tenaga Kerja Wanita pada Usaba Tikar Purun di Desa Pedamaran VI Kecamatan Pedamaran Kabupaten Ogan Komering Ilir.

Nurman. (2015). Strategi Pembangunan Daerah. Jakarta: PT. Raja Grafindo Persada.

Pangaribuan, W., \& Silaban, R. (2017). Upaya Peningkatan Pendapatan Wanita Pengrajin Purun (Eleocharis Dulcis) Di Kecamatan Perbaungan. Jurnal Pengabdian Kepada Masyarakat, 23(2), 309. https://doi.org/10.24114/jpkm.v23i2.6882

Rofiqah Wahdah, \& Amalia, H. S. (2016). Pengembangan Daya Saing Produk pada Sentra Kerajinan Purun di Kabupaten Hulu Sungai Utara Kalimantan Selatan. Jurnal Spread, 6(2), 89-99.

Sánchez-Medina, P. S., Corbett, J., \& Toledo-López, A. (2011). Environmental innovation and sustainability in small handicraft businesses in Mexico. Sustainability, 3(7), 984 1002. https://doi.org/10.3390/su3070984

Sari, C. P. (2014). Peran Kepemimpinan Kepala Desa Dan Pemberdayaan Masyarakat Di Desa Bawuran Kecamatan Pleret Kabupaten Bantul Tahun 2014(Doctoral Dissertation, Fisipol Umy).

Shojanoori, F., Jamali, M., Honarbakhsh, F., Shojanoori, N., \& Akbari, M. (2015). An Analysis of the Environmental Factors Influencing the Handicraft Development. Social Behavior and Personality, 43(10), 2.

Totok Mardikanto, Poerwoko Soebiato. 2017. Pemberdayaan Masyarakat, Bandung: Alfabeta.

Yavari, H, (2011); A cursory look at management in handicrafts production workshops, Azar Publications; Tehran.

Yoesran, M., Gunawansyah, \& R, A. A. (2014). Usaha Peningkatan Produktivitas'Tenaga Kerja dan Nilai Tambah Kerajinan Purun. Jurnal Hutan Tropis, 2, 176-188.

Zulkarnaini \& Maryanti. (2014). Pelaksanaan Program Pemberdayaan Masyarakat Desa. 